Int. J. Plant Sci. 168(8):1141-1149. 2007.

(c) 2007 by The University of Chicago. All rights reserved.

1058-5893/2007/16808-0003\$15.00 DOI: $10.1086 / 520722$

\title{
THE PHI THICKENING IN ROOTS OF BROCCOLI PLANTS: AN ACCLIMATION MECHANISM TO SALINITY?
}

\author{
Luis López-Pérez, Nieves Fernández-García, Enrique Olmos, and Micaela Carvajal ${ }^{1}$
} Departamento de Nutrición Vegetal, Centro de Edafología y Biología Aplicada del Segura-Consejo Superior de
Investigaciones Científicas, P.O. Box 164, 30100, Espinardo, Murcia, Spain

\begin{abstract}
Although broccoli is moderately tolerant to salt stress, the tolerance mechanism is still unknown. Therefore, in this article, the uptake and transport of nutrients and water in relation to the changes in root anatomy (phi thickening appearance) caused by salinity stress have been studied. The effect of phi thickening in the response of these plants to salinity was studied by comparing two methods of measuring root hydraulic conductance, pressurizing roots and natural exudation, and analyzing the nutrient concentrations in the xylem. The permeability properties of phi thickening were tested by a tracer that moves only via the apoplastic pathway. Brassica oleracea $\mathrm{L}$. var. Italica plants, grown under different levels of $\mathrm{NaCl}(0,40$, and $80 \mathrm{mM})$, showed modifications in the cell wall of the cortical layer bordering the endodermis, such as phi thickenings. The results also showed a decrease of the $L_{0}$ and $G_{S}$ of plants under salinity stress and an ionic imbalance in the xylem sap. $\mathrm{Na}^{+}, \mathrm{Mg}^{2+}$, $\mathrm{SO}_{4}^{2-}$, and $\mathrm{Cl}^{-}$concentrations increased, while $\mathrm{Ca}^{2+}$ decreased. The fact that the proportion of apoplastic movement, which was higher when plants were measured with the Scholander chamber than with natural exudation, was lower for $\mathrm{NaCl}$-treated plants whereas the alteration of nutrient uptake was similar suggests that the phi thickenings could be a physical barrier only to apoplastic water transport.
\end{abstract}

Keywords: broccoli, phi thickenings, root anatomy, root hydraulic conductance, salinity, xylem sap nutrient concentration.

\section{Introduction}

Root systems have developed a variety of strategies and mechanisms that enable them to react to stressful changes in their environment. A number of studies have shown alterations in the morphology and fine structure of the root induced by different unfavorable conditions (Peterson 1992; Hose et al. 2001; Enstone et al. 2003). It has been shown that salinity promotes suberization of the hypodermis and endodermis and that the Casparian strip is developed closer to the root tip than in nonsaline roots (Shannon 1997). In cotton seedling roots, the formation of an exodermis, the premature differentiation of protophloem sieve tube members, and the induction of lateral root initiations much closer to the root tip can be induced by salinity (Reinhardt and Rost 1995a, 1995b; Ma and Peterson 2003). In addition, some plant species develop phi thickening in different root tissues, modifications of the midportion of the radial cell walls (Degenhardt and Gimmler 2000) that can form either a uniseriate or a multiseriate layer (Peterson et al. 1981). Phi thickenings were first described in the nineteenth century and consist of nitrocellulose wall deposits that are impregnated with lignin. They usually form on the walls of certain cell layers in the root cortex of some gymnosperms (Haas et al. 1976) and a few families of angiosperms (Peterson et al. 1981; Praktikakis et al. 1998). Although Weerdenburg and Peterson (1983) assumed

1 Author for correspondence; fax 34-968-39-62-13; e-mail mcarvaja@ cebas.csic.es.

Manuscript received November 2006; revised manuscript received May 2007. that phi thickenings function primarily as supportive structures, their role has been the subject of much speculation and experimentation but is still not clear.

Ion and water homeostasis is the main physiological process that plants need to optimize to maintain growth in saline environments (Munns and Termaat 1986; Hasegawa et al. 2000). The effect of salinity on plants is a stress imposed by the reduction of osmotic potential in the soil solution, nutritional imbalance, specific ion effects, and a combination of these factors (Shannon 1997). These deleterious effects modify growth via effects at the physiological and biochemical levels (Munns 2002) and at the molecular level (Winicov 1998). Osmotic adjustment helps plant cells to withstand salinity, and water deficit conditions generate a gradient of water potential between the plant and the substrate, necessary to maintain water uptake and sufficient turgor for growth (Carvajal et al. 1999, 2000). This adjustment implies the regulation of the intracellular levels of organic compounds, such as proline (Jeschke et al. 1986; Djanaguiraman et al. 2006) or glycine betaine (Verslues et al. 2006), and the compartmentation of ions, such as $\mathrm{Mg}^{2+}$ in the cytoplasm and $\mathrm{Na}^{+}, \mathrm{K}^{+}$, and $\mathrm{Cl}^{-}$in the vacuole (Voetberg and Sharp 1991). Also, the high apoplastic concentrations of $\mathrm{Na}^{+}$and $\mathrm{Cl}^{-}$modify the root hydraulic conductance because of a toxic effect that negatively influences the concentration or functionality of aquaporins (Martínez-Ballesta et al. 2000; Navarro et al. 2000, 2003).

Salinity stress also affects the stomatal conductance $\left(G_{\mathrm{S}}\right)$ (Goldstein et al. 1996; Santiago et al. 2000; Djanaguiraman et al. 2006). Bayuelo-Jiménez et al. (2003) reported a decreased $G_{\mathrm{S}}$ in Phaseolus plants grown under salinity because of a 
toxic effect of $\mathrm{Na}^{+}$and $\mathrm{Cl}^{-}$; apart from this, higher concentrations of these ions were capable of reducing $\mathrm{CO}_{2}$ assimilation. They also mentioned that reduced stomatal conductance decreased the photosynthetic carbon assimilation. Similar results have been reported for rice (Djanaguiraman et al. 2006), amaranth (Omami and Hammes 2006), and mangrove (Suárez and Medina 2006).

Broccoli plants, which have been proven to possess anticancer properties, are moderately tolerant to salt stress (LópezBerenguer et al. 2006), although the tolerance mechanism is still unknown. Therefore, the objective of this article was to study the uptake and transport of nutrients and water in relation to the changes in root anatomy (phi thickening appearance) produced by salinity stress. For this, leaf and root osmotic potential, stomatal conductance, and root hydraulic conductivity were measured to check the water relations under salinity. The effect of phi thickening in the response of these plants to salinity was studied by comparing two methods of measuring root hydraulic conductance, pressurizing roots and natural exudation, and analyzing the nutrient concentrations in the xylem. The permeability properties related to phi thickening were tested by using a tracer that moves only via the apoplastic pathway.

\section{Material and Methods}

\section{Plant Culture}

Seeds of broccoli (Brassica oleracea cv. Maratón) were prehydrated with deionized water, continuously aerated, for 12 h. After this, the seeds were germinated in vermiculite in the dark at $28^{\circ} \mathrm{C}$ for $2 \mathrm{~d}$. They were then transferred to a chamber with controlled environmental conditions: a $16 \mathrm{~L}$ : 8D cycle with temperatures of $25^{\circ}$ and $20^{\circ} \mathrm{C}$ and relative humidities of $60 \%$ and $80 \%$, respectively. The PAR was $400 \mu \mathrm{mol} \mathrm{m}^{-2} \mathrm{~s}^{-1}$. After $3 \mathrm{~d}$, the seedlings were placed in 15-L containers with continuously aerated Hoagland nutrient solution: $\mathrm{KNO}_{3}$ $(3.0 \mathrm{mM}), \mathrm{Ca}\left(\mathrm{NO}_{3}\right)_{2}(2.0 \mathrm{mM}), \mathrm{KH}_{2} \mathrm{PO}_{4}(0.5 \mathrm{mM}), \mathrm{MgSO}_{4}$ $(0.5 \mathrm{mM}), \mathrm{H}_{3} \mathrm{BO}_{3}(25.0 \mu \mathrm{M}), \mathrm{MnSO}_{4}(2.0 \mu \mathrm{M}), \mathrm{ZnSO}_{4}$ $(2.0 \mu \mathrm{M}), \mathrm{CuSO}_{4}(0.5 \mu \mathrm{M}),\left(\mathrm{NH}_{4}\right)_{6} \mathrm{Mo}_{7} \mathrm{O}_{24}(0.5 \mu \mathrm{M})$, FeEDTA $(20.0 \mu \mathrm{M})$. The solution was changed every $4 \mathrm{~d}$. After $2 \mathrm{wk}$, the salinity treatments of 0,40 , and $80 \mathrm{mM} \mathrm{NaCl}$ began. Measurements were carried out $1 \mathrm{~d}, 1 \mathrm{wk}$, and $2 \mathrm{wk}$ after applying $\mathrm{NaCl}$.

\section{Osmotic Potential $(\Psi \pi)$}

The most recent fully expanded leaves of broccoli plants of different treatments were selected, placed in Eppendorf tubes with holes at the bottom, and frozen at $-80^{\circ} \mathrm{C}$. These tubes were then placed in centrifuge tubes and centrifuged twice at $4000 \mathrm{rpm}$ for $4 \mathrm{~min}$, using a Hettich-Universal 32R centrifuge in such a way that all sap was extracted from the samples. The osmolarity of the leaf sap was measured with an automatic freezing point depression osmometer (Digital Osmometer, Roebling, Berlin), and the osmotic potential $(\Psi \pi)$ was calculated by the van't Hoff equation (Nobel 1991):

$$
\Psi \pi=n R T,
$$

where $n$ is mosmol, $R=0.0083$, and $T$ is temperature $(\mathrm{K})$. The $\Psi \pi$ was determined $1 \mathrm{~d}, 1 \mathrm{wk}$, and $2 \mathrm{wk}$ after $\mathrm{NaCl}$ application.

\section{Root Hydraulic Conductance $\left(\mathrm{L}_{0}\right)$}

Root hydraulic conductance was measured by natural exudation and by pressurizing the roots using the Scholander chamber. For natural exudation, the aerial parts of the plants were removed, leaving the base of the stem, which was sealed with silicone grease into a tapered plastic tube. They were then left for a specific amount of time $(2 \mathrm{~min}$ for control, 8 $\min$ for $40 \mathrm{mM} \mathrm{NaCl}$, or $15 \mathrm{~min}$ for $80 \mathrm{mM} \mathrm{NaCl}$ ), and the sap accumulated was collected in Eppendorf tubes. The roots and the Eppendorf tubes were weighed in a precision balance. Sap flow $\left(J_{\mathrm{v}}\right)$ was expressed in $\mathrm{mg} \mathrm{g}$ (root fresh weight $)^{-1}$ $\mathrm{h}^{-1}$. The osmolarities of the sap flow and the corresponding nutrient solution were measured. The osmotic pressure difference $(\Delta \Psi \pi)$ between the sap flow and nutrient solution was calculated according to their osmolarity values. The hydraulic conductance was determined by the equation

$$
L_{0}=\frac{J_{\mathrm{v}}}{\Delta \Psi \pi} \operatorname{mg~g}(\text { root fresh weight })^{-1} \mathrm{~h}^{-1} \mathrm{MPa}^{-1}
$$

As a second method of determining $L_{0}$, roots were pressurized in a Scholander pressure chamber. The aerial parts of the plants were removed, and the stems were put in plastic tubes. The roots were placed into a pressure chamber with the same nutrient solution that they were grown in, and a gradual increase of pressure (from 0.1 to $0.4 \mathrm{MPa}$ ) was applied to the detached roots. The sap that was accumulated in this pressure range during a certain time according to the treatment was collected in Eppendorf tubes. The roots and the tubes were weighed in a precision balance. Sap flow $\left(J_{\mathrm{v}}\right)$ was expressed in mg g (root fresh weight) ${ }^{-1} \mathrm{~h}^{-1}$ and plotted against pressure $(\mathrm{MPa})$, with the slope being the $L_{0}$ value in mg $g$ (root fresh weight) ${ }^{-1} \mathrm{~h}^{-1} \mathrm{MPa}^{-1}$. The measurements, both by natural exudation and pressurizing, were made in the middle of the photoperiod, $2 \mathrm{wk}$ after applying $\mathrm{NaCl}$.

\section{Stomatal Conductance $\left(\mathrm{G}_{s}\right)$}

The measurements of $G_{s}$ were made using a portable porometer (AP4 porometer, Delta-T Devices) in the adaxial stomata (more stomata exist on the adaxial surface of broccoli leaves; López-Berenguer et al. 2006) of the most recent fully expanded leaves during the middle of the photoperiod.

\section{Measurement of the Apoplastic Pathway}

Measurements of the apoplastic pathway of water movement were performed using light green dye (light green SF yellowish; Aldrich Chemical, Gillingham, Dorset), which has the ability to move apoplastically but not symplastically (Epel and Bandurski 1990). Dye solution $\left(250 \mu \mathrm{mol} \mathrm{L}^{-1}\right)$ was added $15 \mathrm{~min}$ before each treatment, before collecting sap for the natural exudation and pressure chamber methods. The concentration of the dye was determined immediately with a spectrophotometer (Beckman DU-40UV) at $630 \mathrm{~nm}$. The percentage of apoplastic pathway was calculated from the dye concentration in the sap flow. The concentration of dye in the nutrient solution of each treatment was considered to be $100 \%$. 


\section{Ion Analysis}

For the anion analysis, xylem sap was diluted and injected into a Dionex-D-100 ion chromatograph. An ionpac AS 124-4 $\mathrm{mm}$ (10-32) column and AG $14(4 \times 50 \mathrm{~mm})$ guard column were used. The flow rate was $1 \mathrm{~mL} \mathrm{~min}{ }^{-1}$, with an eluent of $0.5 \mathrm{mM} \mathrm{Na}_{2} \mathrm{CO}_{3} / 0.5 \mathrm{mM} \mathrm{NaHCO}$. The anion concentration was measured with a conductivity detector and quantified with Chromoleon/Peaknet 6.40 software by comparing peak areas with those of known standards. For cation analysis, an ICP plasma analyzer (IRIS Intrepid II XDL, Thermo Electron) was used.

\section{Light Microscopy}

Roots sections ( $3 \mathrm{~mm}$ long) were cut at the apex and 3 and $10 \mathrm{~cm}$ from the tip and were fixed with $2.5 \%$ glutaraldehyde and 3\% paraformaldehyde in $0.1 \mathrm{M}$ sodium phosphate buffer (pH 7.2) for $2.5 \mathrm{~h}$. After three 15 -min washes with the buffer, the specimens were postfixed in $1 \%$ osmium tetroxide in the same buffer for $2 \mathrm{~h}$. After this, three washes with phosphate buffer were performed, and the samples were left overnight at $4^{\circ} \mathrm{C}$. All fixed tissues were dehydrated in a graded series of ethanol $(35 \%, 50 \%, 70 \%, 96 \%$, and $100 \%)$ and then infiltrated, first with propylene oxide and then with propylene oxide and spurr resin mixture. The samples were then immersed in spurr resin overnight at $4^{\circ} \mathrm{C}$. Finally, the samples were embedded in spurr resin. Sections $1 \mu \mathrm{m}$ thick were cut with a Reichert ultramicrotome and mounted on glass slides. Semithin sections were stained with toluidine blue and observed with a Leica DMR light microscope.

\section{Histochemical Stain for Lignin (Phloroglucinol)}

Semithin sections were soaked in $1.0 \%(\mathrm{w} / \mathrm{v})$ phloroglucinol in $25: 75(\mathrm{v} / \mathrm{v}) \mathrm{HCl}$-ethanol for $10-15 \mathrm{~min}$. The stained sections were observed and photographed with a Leica DMR light microscope.

\section{Data Analysis}

Variance analysis and Tukey's HSD test were carried out to determine differences among treatments, using SYSTAT 9.0 software for Windows.

\section{Results}

\section{Effect of Salinity on Osmotic Potential}

Root and leaf osmotic potential of broccoli plants decreased significantly after adding $\mathrm{NaCl}$ to the nutrient solution. The reduction was greater for leaves and roots from plants treated with $80 \mathrm{mM} \mathrm{NaCl}$ (fig. 1), with the differences between 40 and $80 \mathrm{mM} \mathrm{NaCl}$ being higher in leaves than in roots. The strongest decrease with respect to control plants was observed during the first day of treatment in roots and leaves for both salinity treatments. After that, the decrease was less and was maintained practically constant until the end of the assay.

\section{Effect of Salinity on Hydraulic Conductance}

Root hydraulic conductance $\left(L_{0}\right)$ values of broccoli plants for different treatments were measured by natural exudation

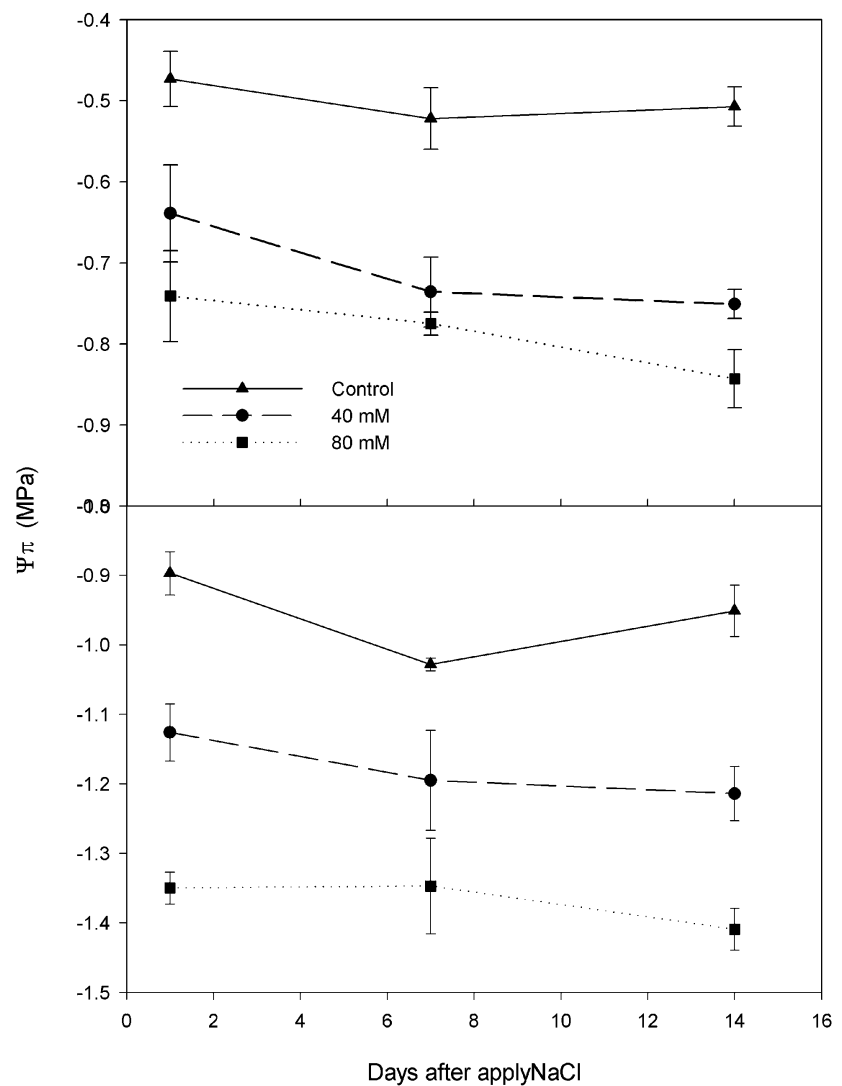

Fig. 1 Osmotic potential $\left(\Psi_{\pi}\right)$ of roots (top) and leaves (bottom) of control and 40 and $80 \mathrm{mM} \mathrm{NaCl}$-treated broccoli plants $(n=$ $5 \pm \mathrm{SE})$.

and by using the Scholander chamber 2 wk after applying $\mathrm{NaCl}$ (fig. 2). There were slight differences in the $L_{0}$ values between the natural exudation and Scholander chamber methods in control and $40 \mathrm{mM} \mathrm{NaCl}$-treated plants: higher $L_{0}$ values were obtained with the pressure chamber. The $L_{0}$, determined by both methods, decreased significantly in plants treated with $\mathrm{NaCl}$, with respect to control plants. This reduction was higher in plants receiving $80 \mathrm{mM} \mathrm{NaCl}$. The $L_{0}$ determined by the pressure chamber decreased by $66 \%$ and $80 \%$ with 40 and $80 \mathrm{mM} \mathrm{NaCl}$, respectively, compared with control plants. The $L_{0}$ determined by natural exudation decreased by $45 \%$ and $63 \%$, respectively, compared with control plants.

\section{Measurement of Apoplastic and Cell-to-Cell Pathways}

The movement of water via the apoplastic pathway was significantly higher when measured by the pressure chamber, with respect to natural exudation, in control plants (table 1). The percentage of water movement via the apoplastic pathway decreased for both methods with increasing $\mathrm{NaCl}$ in the nutrient solution. In the absence of $\mathrm{NaCl}, 75 \%$ of water was transported in plants by the cell-to-cell pathway, whereas for plants receiving $\mathrm{NaCl}$, the value was $96 \%$. For the natural exudation technique, $99 \%$ of water was transported by the cellto-cell pathway for all treatments. 


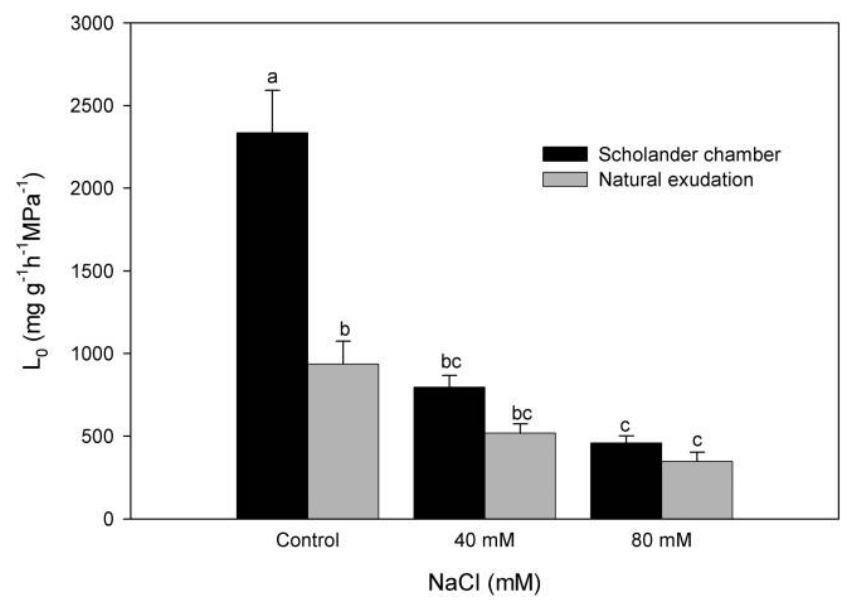

Fig. 2 Root hydraulic conductance $\left(L_{0}\right)$ of control and 40 and 80 $\mathrm{mM} \mathrm{NaCl}$-treated broccoli plants, determined using a Scholander chamber or natural exudation $14 \mathrm{~d}$ after applying salinity stress $(n=$ $5 \pm \mathrm{SE}$ ). Columns with the same letters are not significantly different $(P<0.05$, Tukey test $)$.

\section{Effect of Salinity on Stomatal Conductance}

The stomatal conductance $\left(G_{s}\right)$ was measured every $3 \mathrm{~d}$ after $\mathrm{NaCl}$ application (fig. 3). In control plants, $G_{s}$ values increased slightly during the first $4 \mathrm{~d}$ of measurements. In plants treated with $\mathrm{NaCl}$, the $G_{\mathrm{s}}$ decreased significantly with respect to control plants, with the decrease being greater in plants treated with $80 \mathrm{mM} \mathrm{NaCl}$ at all times of measurement.

\section{Xylem Sap Ion Concentrations}

The cation concentrations of xylem sap obtained by the natural exudation and Scholander chamber methods were determined in all treatments $2 \mathrm{wk}$ after $\mathrm{NaCl}$ application (fig. 4). For the Scholander chamber, the analyzed sap was obtained at a pressure equivalent to transpiration $(0.4 \mathrm{MPa})$. The $\mathrm{K}^{+}$concentration was much higher than other cations, and it was much higher when the xylem sap was extracted by natural exudation. Nevertheless, there was no significant difference in the $\mathrm{K}^{+}$concentration between treatments separately comparing both methods. The $\mathrm{Na}^{+}, \mathrm{Ca}^{2+}$, and $\mathrm{Mg}^{2+}$ concentrations increased significantly after applying $\mathrm{NaCl}$ when the xylem sap was extracted by the Scholander chamber. There were no significant differences in the $\mathrm{Mg}^{2+}$ concentrations between control and $\mathrm{NaCl}$-treated plants when the xylem sap was extracted by natural exudation; the $\mathrm{Ca}^{2+}$ concentration decreased significantly, and the $\mathrm{Na}^{+}$concentration increased.

The analysis of anion concentrations in xylem sap (fig. 5) showed that $\mathrm{Cl}^{-}$and $\mathrm{SO}_{4}^{2-}$ increased significantly after applying $\mathrm{NaCl}$, being highest in plants treated with $80 \mathrm{mM} \mathrm{NaCl}$. However, the concentration of $\mathrm{Cl}^{-}$was higher obtained by the Scholander chamber, and the concentration of $\mathrm{SO}_{4}^{2-}$ was higher obtained by natural exudation. The $\mathrm{NO}_{3}^{-}$concentrations were higher when the xylem sap was extracted by natural exudation but were significantly increased only by the treatment under pressure. There was no difference in the $\mathrm{PO}_{4}^{3-}$ concentration between control plants and those treated with $\mathrm{NaCl}$, when the sap was determined by both the natural exudation and Scholander chamber methods.

\section{Effect of Salinity on Root Cell Anatomy}

There were no significant effects of $\mathrm{NaCl}$ on the length of the roots $(P=0.445)$, with the mean root length being $54.364 \pm 1.34 \mathrm{~cm}$. Observations of the thin root sections with the microscope revealed a cell wall modification resembling phi thickenings in the cell walls of the internal cortical layer, proximal to the endodermis (fig. 6). These phi thickenings were present in all treatments, but there were more in plants treated with $\mathrm{NaCl}$, and they were thicker in the presence of $80 \mathrm{mM} \mathrm{NaCl}$ (fig. 6C-6F). This thickening increased with time in $\mathrm{NaCl}$-treated plants (fig. $6 F$ ). Thickenings were not formed continuously from the root tip to the base but were clearly evident in the portion $10 \mathrm{~cm}$ from the tip, the oldest part of the root.

\section{Discussion}

Salinity stress affects the water relations in plants (Zhu 2001), since it decreases the water potential in the environment surrounding the roots. This effect leads to an osmotic adjustment that involves the net accumulation of solutes in order to absorb water (Verslues et al. 2006). For this, plants have to decrease their internal water potential, which implies a decrease of the osmotic potential to maintain turgor and achieve osmotic adjustment (Blum et al. 1996). Therefore, the fact that in our plants a decrease in osmotic potential in leaves and roots was observed in relation to $\mathrm{NaCl}$ addition (fig. 1) could indicate a good osmotic adjustment. Also, the increase of the $\mathrm{Na}^{+}$and $\mathrm{Cl}^{-}$concentrations detected in the sap flow after the $\mathrm{NaCl}$ addition (figs. 4, 5) could support the idea that the osmotic adjustment is produced in part by ion accumulation. These ions are involved in osmoregulation, although both are toxic at high concentrations (Munns 2002; Essah et al. 2003).

The root hydraulic conductance is known to change under high salinity (Carvajal et al. 1999). López-Berenguer et al. (2006) reported a decreased $L_{0}$ for broccoli plants $1 \mathrm{wk}$ after applying different concentrations of $\mathrm{NaCl}$. The effect of salinity on the $L_{0}$ in other species (Shalhevet et al. 1976; Munns and Passioura 1984; Evlagon et al. 1990; Azaizeh and Steudle 1991) has been suggested to be due to the osmotic effect of $\mathrm{Na}^{+}$ and $\mathrm{Cl}^{-}$. However, Carvajal et al. (1999, 2000) and MartínezBallesta et al. $(2000,2004)$ suggested that the decrease of $L_{0}$

\section{Table 1}

Apoplastic Pathway Percentage, Measured by Apoplastic Tracer Light Green Dye, for Control and 40 and $80 \mathrm{mM} \mathrm{NaCl}$ Plants

\begin{tabular}{lcc}
\hline Treatments & Scholander chamber & Natural exudation \\
\hline Control & $26.64 \pm 3.10^{\mathrm{a}}$ & $.92 \pm .03^{\mathrm{a}}$ \\
$40 \mathrm{mM} \mathrm{NaCl}$ & $4.88 \pm .74^{\mathrm{b}}$ & $.77 \pm .08^{\mathrm{ab}}$ \\
$80 \mathrm{mM} \mathrm{NaCl}$ & $4.56 \pm .61^{\mathrm{b}}$ & $.53 \pm .07^{\mathrm{b}}$ \\
\hline
\end{tabular}

Note. Data determined using a Scholander pressure chamber or by natural exudation $14 \mathrm{~d}$ after applying salinity stress $(n=5 \pm \mathrm{SE})$. Means with different letters in columns are statistically different $(P<$ $0.05)$. 


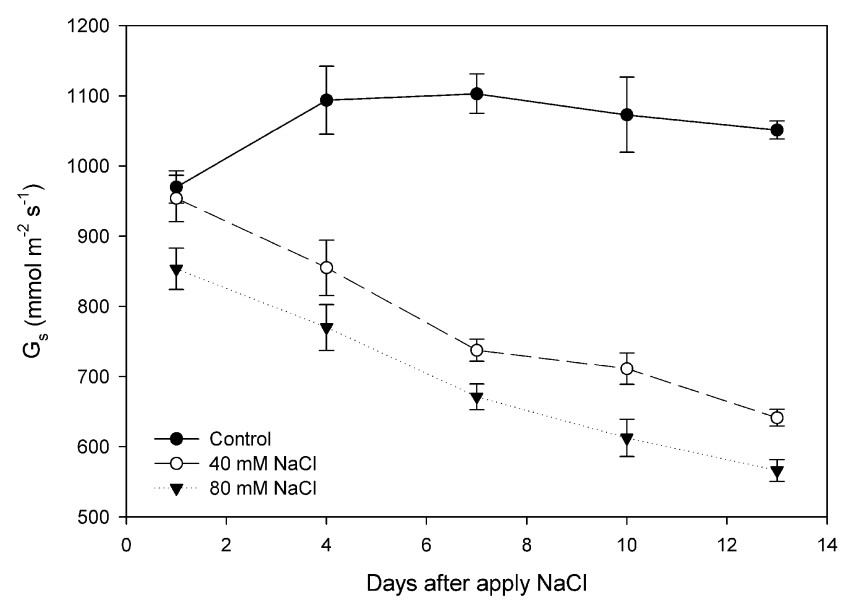

Fig. 3 Leaf stomatal conductance $\left(G_{\mathrm{S}}\right)$ of control and 40 and 80 $\mathrm{mM} \mathrm{NaCl}$ plants $(n=8 \pm \mathrm{SE})$.

was due to a toxic effect of $\mathrm{Na}^{+}$and $\mathrm{Cl}^{-}$, which mainly reduces the water transport through the plasma membrane. They also reported that a large reduction in root hydraulic conductance was related to the activity or concentration of aquaporins in the root plasma membrane. In our experiments, the higher concentrations of $\mathrm{Na}^{+}$and $\mathrm{Cl}^{-}$found in the sap and exudate of plants exposed to salinity (figs. 4,5 ) could have had a toxic effect on aquaporin functionality. The treatments with $\mathrm{NaCl}$ produced a reduction in $L_{0}$ with respect to control plants (fig. 2). This decrease was $73 \%$ when determined using the Scholander chamber and $54 \%$ when determined by natural exudation. The fact that the flows were higher when measured using the Scholander chamber could be a consequence of pressurizing the roots. In this case, water movement occurs through the apoplast to a greater extent than when the measurements are carried out by natural exudation. Similar results were reported by Fernández-García et al. (2002) with tomato plants. This suggestion is confirmed by the data obtained from the experiment with the light green dye (table 1). However, the fact that the apoplastic pathway proportion, which was increased when plants were measured with the Scholander chamber, was not similar for all treatments (being much lower for $\mathrm{NaCl}$-treated plants) suggests that the phi thickenings (fig. 6) could be a physical barrier to apoplastic water transport.

The significant decrease in $G_{S}$ observed in plants treated with $\mathrm{NaCl}$, with respect to control plants (fig. 3), was probably caused by closure of the stomata (Robinson et al. 1997) or decreased water uptake through the roots. Similar results were reported in pepper (Cabañero et al. 2004; Martínez-Ballesta

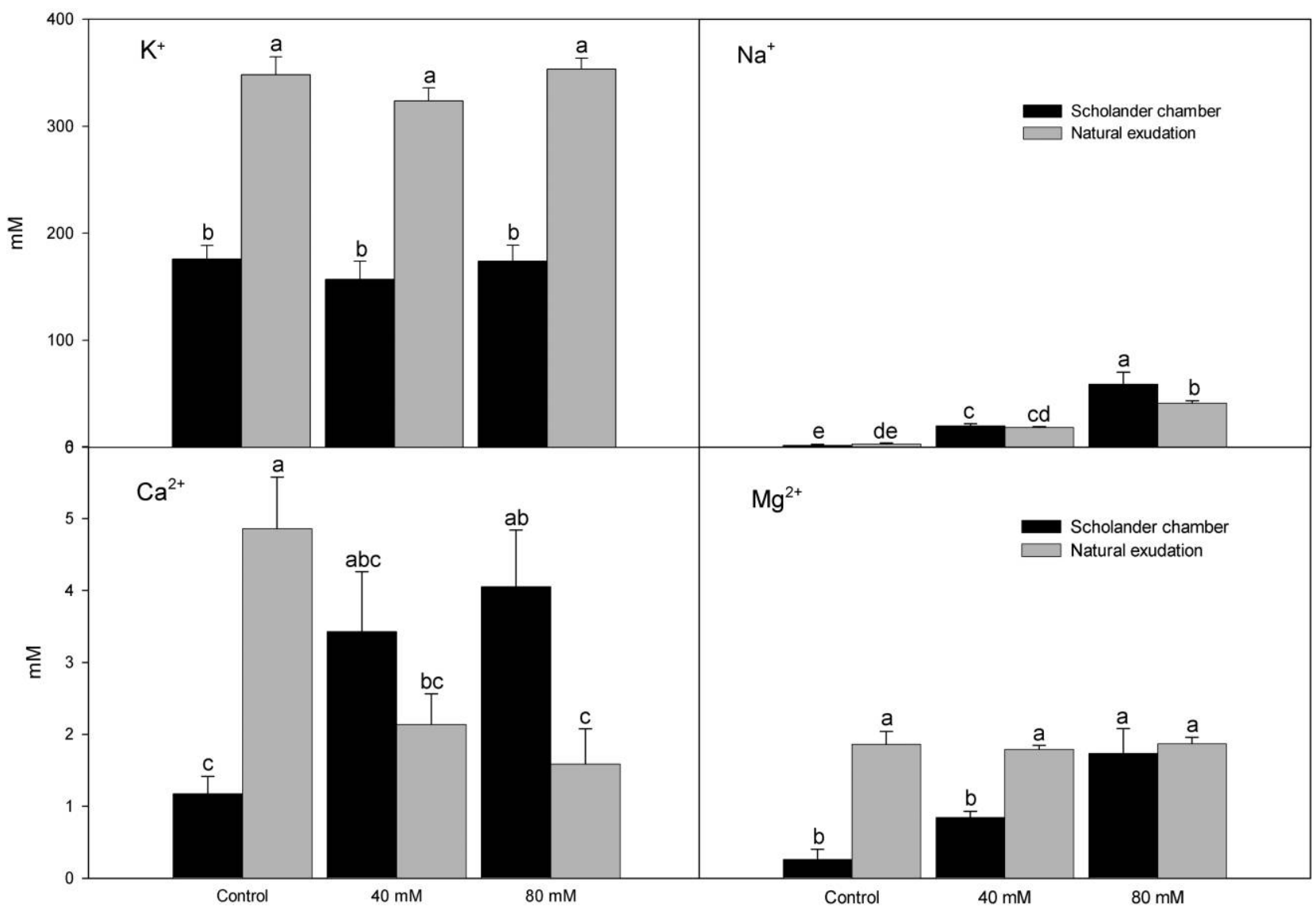

Fig. 4 Cation concentrations $\left(\mathrm{K}^{+}, \mathrm{Na}^{+}, \mathrm{Ca}^{2+}\right.$, and $\left.\mathrm{Mg}^{2+}\right)$ in the xylem sap of control and 40 and $80 \mathrm{mM} \mathrm{NaCl-treated} \mathrm{broccoli} \mathrm{plants,} \mathrm{obtained}$ by using natural exudation or a Scholander pressure chamber $14 \mathrm{~d}$ after applying salinity stress $(n=5 \pm \mathrm{SE})$. Columns with the same letters are not significantly different $(P<0.05$, Tukey test). 


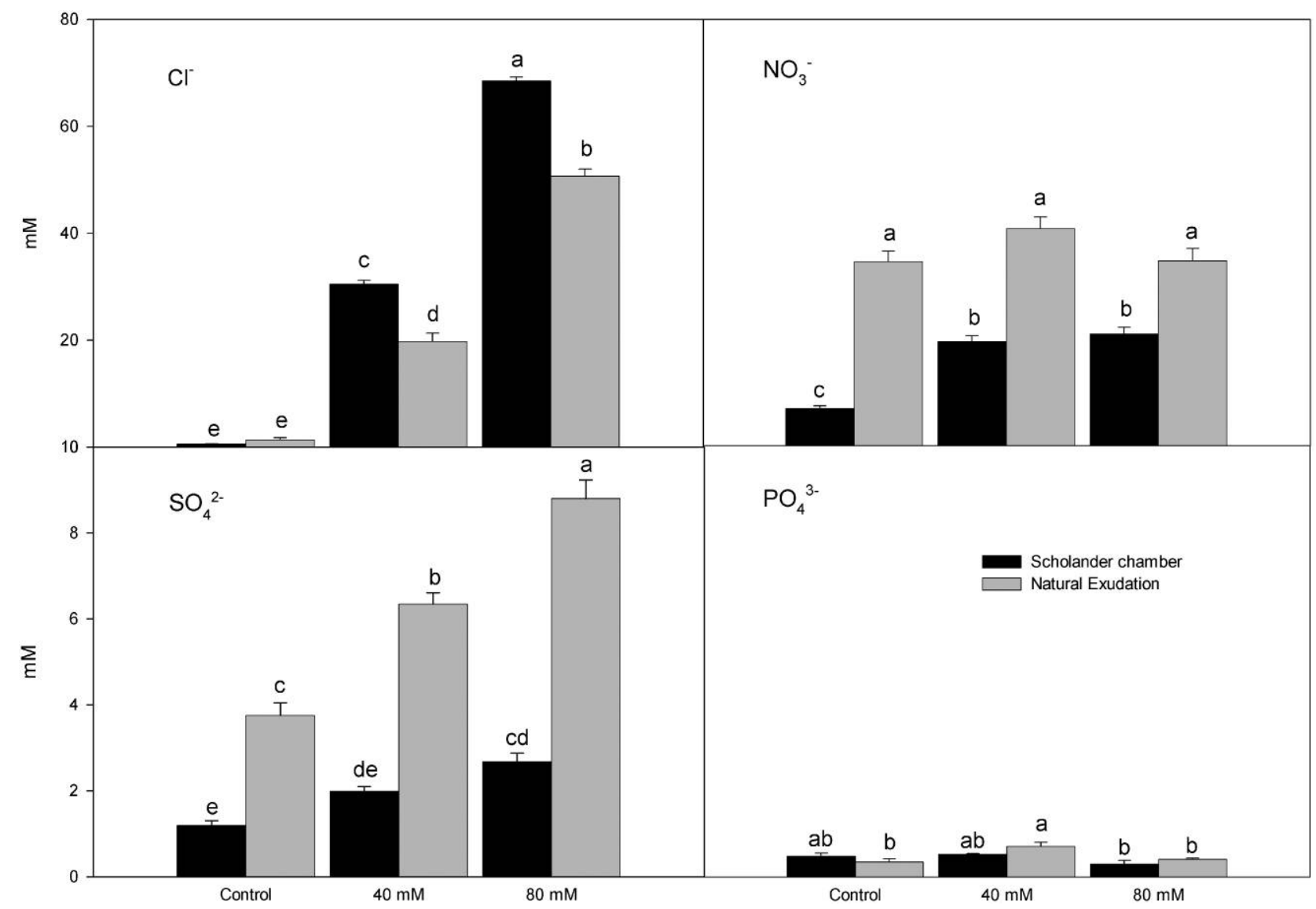

Fig. 5 Anion concentrations $\left(\mathrm{Cl}^{-}, \mathrm{NO}_{3}^{-}, \mathrm{SO}_{4}^{2-}\right.$, and $\left.\mathrm{PO}_{4}^{3-}\right)$ in the xylem sap of control and 40 and $80 \mathrm{mM} \mathrm{NaCl-treated} \mathrm{broccoli} \mathrm{plants,}$ obtained by using natural exudation or a Scholander pressure chamber $14 \mathrm{~d}$ after applying salinity stress $(n=5 \pm \mathrm{SE})$. Columns with the same letters are not significantly different $(P<0.05$, Tukey test).

et al. 2004), Phaseolus (Bayuelo-Jiménez et al. 2003), and broccoli (Ashraf 2001; López-Berenguer et al. 2006). A reduction in $G_{S}$ could indicate a certain level of acclimation to salinity stress (Munns and Termaat 1986). The decreased $G_{\text {s }}$ also could be due to higher concentrations of $\mathrm{Na}^{+}$and $\mathrm{Cl}^{-}$in the leaf sap (figs. 4, 5). García-Legaz et al. (1993) and Walker et al. (1993) proposed that the reduction of leaf gas exchange in response to salinity is due to an increase in leaf $\mathrm{Na}^{+}$concentration. However, Bañuls et al. (1997) and García-Sánchez et al. (2002a, $2002 b$ ) associated reductions in stomatal conductance with high $\mathrm{Cl}^{-}$concentrations.

The $\mathrm{NaCl}$ addition to the nutrient solution obviously caused a significant increase in $\mathrm{Na}^{+}$and $\mathrm{Cl}^{-}$in the xylem sap (figs. 4, 5). The decreased $\mathrm{SO}_{4}^{2-}, \mathrm{NO}_{3}^{-}$, and $\mathrm{Mg}^{2+}$ concentrations in the xylem when sap was obtained by the Scholander chamber suggest that these ions were diluted as a consequence of pressurizing the roots that caused more water movement through the apoplast. Similar results were reported in tomato (Fernández-García et al. 2002). However, if the flux of solutes into the xylem is calculated for both methods, similar results are obtained (data not shown). The $\mathrm{Cl}^{-}$concentration obtained by the Scholander chamber was found to be very similar to that of the outside nutrient solution, which could indicate that it is passively transported into the root system. The decrease in $\mathrm{Ca}^{2+}$ concentration obtained with salinity has been reported previously (Savvas and Lenz 1994; Sánchez-Raya and Delgado 1996; Martínez-Ballesta et al. 2004). Under saline conditions, disorders may result from effects on $\mathrm{Ca}^{2+}$ availability, competitive uptake, transport, or partitioning within the plant (Grattan and Grieve 1999). Salinity has been shown to induce calcium deficiency in different species and affects water relations to a great extent (Kaya et al. 2002; Cabañero et al. 2004). Our results in previous experiments with pepper plants showed that salinity reduced the concentration of calcium in roots (intraand extracellular) and that it was restored when $\mathrm{Ca}^{2+}$ was added to salinity-stressed plants (Cabañero et al. 2006). However, the fact that the $\mathrm{Ca}^{2+}$ concentration was increased with salinity treatments when it was obtained by the Scholander chamber needs to be assessed.

The broccoli plants grown with $\mathrm{NaCl}$ showed anatomical root cell changes. The most important modification in the anatomy of the root was phi thickening in some cases, with the typical shape of phi in the internal cortical layer. Two layers were detected (fig. $6 \mathrm{D}, 6 \mathrm{E}$ ). It is the first time that the presence of cell wall modifications, like thickenings, has been reported in broccoli as a response to salinity. This thickening has been reported in other Brassica species such as Brassica napus (Enstone et al. 2003), but this was under flooding stress. Phi thickenings have been described already for other species (Haas et al. 1976; Mackenzie 1979; Peterson et al. 

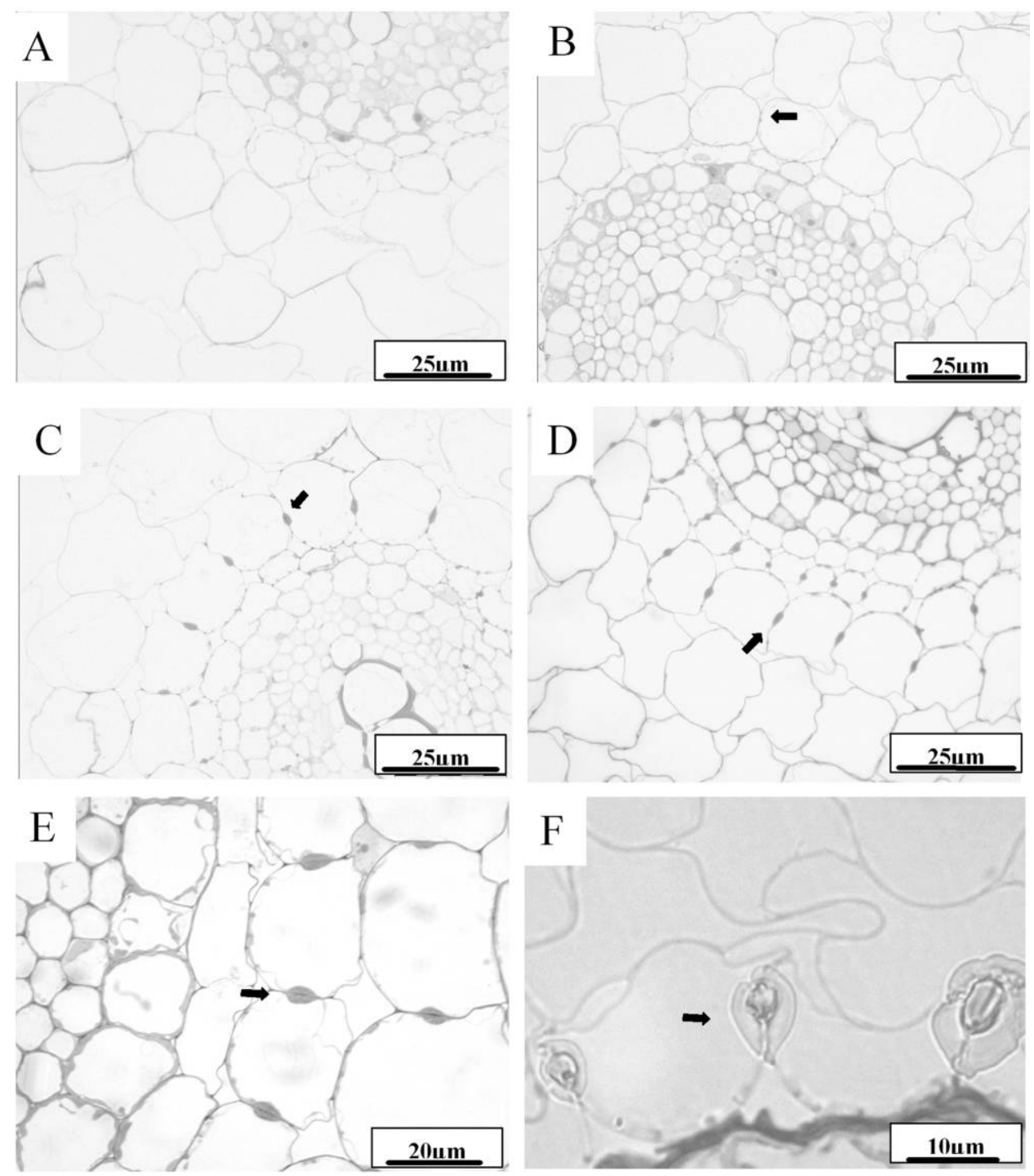

Fig. 6 Light microscopy showing phi thickenings in the cell walls of the cortical layer surrounding the endodermis (arrows) of control broccoli plants $(A, B)$ and of $80 \mathrm{mM} \mathrm{NaCl}$-treated plants $(C-F)$. All images are at $10 \mathrm{~cm}$ from the tip and after $14 \mathrm{~d}$ of salinity treatment.

1981; Weerdenburg and Peterson 1983; Praktikakis et al. 1998; Degenhardt and Gimmler 2000; Gerrath et al. 2002, 2005; Soukup et al. 2004), but no special conditions were reported to be necessary to induce them. However, in Ceratonia siliqua, a phi layer appeared only when plants were grown in soil, not in perlite (Praktikakis et al. 1998). Also, in maize, phi thickenings were detected only in slag culture (Degenhardt and Gimmler 2000) but with no alteration under stress conditions. However, in our experiment, phi thickenings increased in salinity-stressed plants. In these plants, the apoplastic pathway was reduced by $60 \%$ with respect to control plants, which probably indicates that phi thickenings were affecting the apoplastic inflow of water, but not ions, to the stele. It has been shown that the functionality of aquaporins was greatly reduced in $\mathrm{NaCl}$-treated broccoli plants in the short term $(7 \mathrm{~d})$ but to a lesser extent in the longer term (14 d) (López-Berenguer et al. 2006), which is directly re- lated to water flow through the symplastic pathway. The fact that phi thickening developed after $14 \mathrm{~d}$, when aquaporins functionality was partially restored, might provide an acclimation mechanism under salinity stress, in which plants can control water uptake.

The results of these experiments indicate that modifications in the cell walls of cortical cells could be an acclimation mechanism of broccoli plants to salinity stress. Such a mechanism certainly requires further investigation, but the fact that this layer could act as a physical barrier to the apoplastic pathway of this plant in saline conditions is a novel finding. Although, in the future, it will be a challenge to find out the physicochemical properties of the phi thickening and relate these to the permeability through both the symplastic and apoplastic pathways, the fact that these plants can regulate their water uptake under saline conditions implies a valuable physiological acclimation. 


\section{Acknowledgments}

We thank Dr. D. Walker for correction of the English in the manuscript. L. López-Pérez was supported by a doctoral fellowship from the Programa de Mejoramiento del Profesorado (Secretaria de Educación Pública), Mexico. This work was funded by the Centro de Investigación Científica y Tecnológica (AGL2005-00650/AGR).

\section{Literature Cited}

Ashraf M 2001 Relationship between growth and gas exchange characteristics in some salt-tolerant amphidiploid Brassica species in relation to their diploid parents. Environ Exp Bot 45:155-163.

Azaizeh H, E Steudle 1991 Effects of salinity on water transport of excised maize (Zea mays L.) roots. Plant Physiol 97:1136-1145.

Bañuls J, MD Serna, F Legaz, E Primo-Millo 1997 Growth and gas exchange parameters of citrus plants stressed with different salts. J Plant Physiol 150:194-199.

Bayuelo-Jiménez JS, DG Debouck, JP Lynch 2003 Growth, gas exchange, water relations, and ion composition of Phaseolus species grown under saline conditions. Field Crops Res 80:207-222.

Blum A, R Munns, JB Passioura, NC Turner 1996 Genetically engineered plants resistant to soil drying and salt stress: how to interpret osmotic relations? Plant Physiol 110:1051-1053.

Cabañero FJ, V Martínez, M Carvajal 2004 Does calcium determine water uptake under saline conditions in pepper plants, or is it water flux which determines calcium uptake? Plant Sci 166: 443-450.

Cabañero FJ, MC Martínez-Ballesta, JA Teruel, M Carvajal 2006 New evidence about the relationship between water channel activity and calcium in salinity-stressed pepper plants. Plant Cell Physiol 47: 224-233.

Carvajal M, A Cerdá, CF Alcaraz 2000 Does calcium ameliorate the negative effect of $\mathrm{NaCl}$ on melon root water transport by regulating aquaporin activity? New Phytol 145:439-447.

Carvajal M, V Martínez, CF Alcaraz 1999 Physiological function of water channels, as affected by salinity in roots of paprika pepper. Physiol Plant 105:95-101.

Degenhardt B, H Gimmler 2000 Cell wall adaptations to multiple environmental stresses in maize roots. J Exp Bot 51:595-603.

Djanaguiraman M, AJ Sheeba, KA Shanker, DD Devi, U Bangarusamy 2006 Rice can acclimate to lethal level of salinity by pretreatment with sublethal level of salinity through osmotic adjustment. Plant Soil 284:363-373.

Enstone ED, AC Peterson, F Ma 2003 Root endodermis and exodermis: structure, function, and responses to the environment. J Plant Growth Regul 21:335-351.

Epel BL, RS Bandurski 1990 Tissue to tissue symplastic communication in the shoots of etiolated corn seedlings. Physiol Plant 79: 604-609.

Essah PA, R Davenport, M Tester 2003 Sodium influx and accumulation in Arabidopsis. Plant Physiol 133:307-318.

Evlagon D, Y Ravina, PM Neumann 1990 Interactive effects of salinity and calcium on hydraulic conductivity, osmotic adjustment and growth in primary roots of maize seedlings. Israel J Bot 39:239247.

Fernández-García N, V Martínez, A Cerdá, M Carvajal 2002 Water and nutrient uptake of grafted tomato plants grown under saline conditions. J Plant Physiol 159:899-905.

García-Legaz MF, JM Ortiz, AG García-Lidon, A Cerdá 1993 Effect of salinity on growth, ion content and $\mathrm{CO}_{2}$ assimilation rate in lemon varieties on different rootstock. Physiol Plant 89:427-432.

García-Sánchez F, J Jofon, M Carvajal, JP Syvertsen 2002a Gas exchange, chlorophyll and nutrients contents in relation to $\mathrm{Na}^{+}$and $\mathrm{Cl}^{-}$accumulation in "Sunburst" mandarin grafted on different rootstocks. Plant Sci 162:705-712.

García-Sánchez F, V Martínez, J Jofon $2002 b$ Salinity reduces growth, gas exchange, chlorophyll and nutrient concentration in diploid sour orange and related allotetraploid somatic hybrids. J Hortic Sci Biotech 77:379-386.

Gerrath JM, L Covington, J Doubt, DW Larson 2002 Occurrence of phi thickenings is correlated with gymnosperm systematics. Can J Bot 80:852-860.

Gerrath JM, U Matthes, M Purich, DW Larson 2005 Root environmental effects on phi thickening production and root morphology in three gymnosperms. Can J Bot 83:379-385.

Goldstein G, DR Drake, C Alpha, P Melcher, J Heraux, A Azocar 1996 Growth and photosynthetic responses of Scaevola sericea, a Hawaiian coastal shrub, to substrate salinity and salt spray. Int J Plant Sci 157: 171-179.

Grattan SR, CM Grieve 1999 Salinity-mineral nutrient relations in horticultural crops. Sci Hortic 78:127-157.

Haas DL, ZB Carothers, RR Robbins 1976 Observations on the phithickenings and Casparian strips in Pelargonium roots. Am J Bot 63:863-867.

Hasegawa PM, RA Bressan, JK Zhu, HJ Bohnert 2000 Plant cellular and molecular responses to high salinity. Annu Rev Plant Physiol Plant Mol Biol 51:463-499.

Hose E, DT Clarkson, E Steudle, L Schreiber, W Hartung 2001 The exodermis: a variable apoplastic barrier. J Exp Bot 52:2245-2264.

Jeschke WD, Z Aslam, H Greenway 1986 Effects of $\mathrm{NaCl}$ on ion relations and carbohydrate status of root and on osmotic regulation of roots and shoots of Atriplex amnicola. Plant Cell Environ 9: 559-569.

Kaya C, H Kirnak, D Higgs, K Saltali 2002 Supplementary calcium enhances plant growth and fruit yield in strawberry cultivars grown at high $(\mathrm{NaCl})$ salinity. Sci Hortic 93:65-74.

López-Berenguer C, C García-Viguera, M Carvajal 2006 Are root hydraulic conductivity responses to salinity controlled by aquaporins in broccoli plants? Plant Soil 279:13-23.

Ma F, CA Peterson 2003 Current insights into development, structure, and chemistry of the endodermis and exodermis of root. Can J Bot 81:405-421.

Mackenzie KAD 1979 The development of the endodermis and phi layer of apple roots. Protoplasma 100:21-32.

Martínez-Ballesta MC, V Martínez, M Carvajal 2000 Regulation of water channel activity in whole roots and in protoplast from roots of melon plants grown under saline conditions. Aust J Plant Physiol 27:685-691.

2004 Osmotic adjustment, water relations and gas exchange in pepper plants grown under $\mathrm{NaCl}$ or $\mathrm{KCl}$. Environ Exp Bot 52: 161-174.

Munns R 2002 Comparative physiology of salt and water stress. Plant Cell Environ 25:239-250.

Munns R, JB Passioura 1984 Hydraulic resistance of plants. III. Effects of $\mathrm{NaCl}$ in barley and lupin. Aust J Plant Physiol 11:351-359.

Munns R, A Termaat 1986 Whole plant responses to salinity. Aust J Plant Physiol 13:143-160.

Navarro JM, C Garrido, V Martínez, M Carvajal 2003 Water relations and xylem transport of nutrients in pepper plants grown under two different salts stress regimes. Plant Growth Regul 41:237-245.

Navarro JM, V Martínez, M Carvajal 2000 Ammonium, bicarbonate and calcium effects on tomato plants grown under saline conditions. Plant Sci 157:89-96. 
Nobel PS 1991 Physicochemical and environmental plant physiology. Academic Press, San Diego, CA. 300 pp.

Omami EN, PS Hammes 2006 Interactive effects of salinity and water stress on growth, leaf water relations, and gas exchange in amaranth (Amaranthus spp). N Z J Crop Hortic Sci 34:33-44.

Peterson CA, ME Emanuel, CA Weerdenburg 1981 The permeability of phi thickenings in apple (Pyrus malus) and geranium (Pelargonium hortoruin) roots to an apoplastic fluorescent dye tracer. Can J Bot 59:1107-1110.

Peterson RL 1992 Adaptation of root structure in relation to biotic and abiotic factors. Can J Bot 70:661-675.

Praktikakis E, S Rhizopoulou, GK Psaras 1998 A phi layer in roots of Ceratonia siliqua L. Bot Acta 111:93-98.

Reinhardt DH, TL Rost 1995 a Developmental changes of cotton root primary tissues induced by salinity. Int J Plant Sci 156:505-513.

- 1995b Salinity accelerates endodermal development and induces an exodermis in cotton seedling roots. Environ Exp Bot 35: 563-574.

Robinson MF, AA Véry, D Sanders, TA Mansfield 1997 How can stomata contribute to salt tolerance? Ann Bot 80:387-393.

Sánchez-Raya AJ, IC Delgado 1996 Mineral nutrient transport by sunflower seedlings grown under salinity conditions $(\mathrm{NaCl})$. J Plant Nutr 19:1463-1475.

Santiago LS, TS Lau, PJ Melcher, OC Steele, G Goldstein 2000 Morphological and physiological response of Hawaiian Hibiscus tiliaceus populations to light and salinity. Int J Plant Sci 161:99-106.

Savvas D, F Lenz 1994 Influence of $\mathrm{NaCl}$ concentration in the nutrient solution on mineral composition of eggplants grown in sand culture. Angew Bot 70:124-127.
Shalhevet J, EV Maas, GJ Hoffman, G Ogata 1976 Salinity and the hydraulic conductance of roots. Physiol Plant 38:224-232.

Shannon MC 1997 Adaptation of plants to salinity. Adv Agron 60: 75-119.

Soukup A, J Malá, M Hrubcová, J Kálal, O Votrubová, M Cvikrová 2004 Differences in anatomical structure and lignin content of roots of pedunculate oak and wild cherry-tree plantlets during acclimation. Biol Plant 48:481-489.

Suárez N, E Medina 2006 Influence of salinity on $\mathrm{Na}^{+}$and $\mathrm{K}^{+}$accumulation, and gas exchange in Avicennia germinans. Photosynthetica 44: 268-274.

Verslues PE, M Agarwal, S Kativyar-Agarwal, J Zhu, J-K Zhu 2006 Methods and concepts in quantifying resistance to drought, salt and freezing, abiotic stresses that affect plant water status. Plant J 45:523-539.

Voetberg GS, RE Sharp 1991 Growth of maize primary root at low water potentials. III. Role of increased proline deposits in osmotic adjustment. Plant Physiol 96:1125-1130.

Walker RR, DH Blackmore, Q Sung 1993 Carbon dioxide assimilation and foliar ion concentration in leaves of lemon (Citrus limon L.) trees irrigated with $\mathrm{NaCl}$ or $\mathrm{Na}_{2} \mathrm{SO}_{4}$. Aust J Plant Physiol 20: 173-185.

Weerdenburg CA, CA Peterson 1983 Structural changes in phi thickenings during primary and secondary growth in roots. 1. Apple (Pyrus malus) Rosaceae. Can J Bot 61:2570-2576.

Winicov I 1998 New molecular approaches to improving salt tolerance in crop plants. Ann Bot 82:703-710.

Zhu JK 2001 Cell signaling under salt, water and cold stresses. Curr Opin Plant Biol 4:401-406. 
